\title{
Political Identity Of Ethnic Batak In Southeast Aceh
}

\author{
Riza Utomo, Hidayat Amsani, Fikarwin Zuska \\ Departement of Anthropology \\ State University of Medan \\ Medan, Indonesia \\ Email: riza.utomo1990@gmail.com
}

\begin{abstract}
This study describes the Batak ethnic identity politics in Southeast Aceh Regency, identity politics became the main focus in the context of the direct election, As one of the ethnic groups in Southeast Aceh Regency ethnicity plays an important role in the political life in Southeast Aceh. Regional autonomy has given place to the widest certain ethnicity to show his political identity. The opening of political access for every ethnic in regency in the Indonesia certainly gives positive impact to the politic world at this time. This research method using descriptive qualitative method. The data collection methods include observation, interviews and documentation study. The results showed that in the era of regional autonomy of ethnic Batak began to show its strength to be able to perform on the stage of the selection of the regions in Southeast Aceh Regency, although not the first time her ethnic Batak to appear on the stage of the election, in 2012 the ethnic Batak also appeared in the elections but is only able to appear in the position of vice only. In 2017 at this time the ethnic Batak also comes with a higher position that as a candidate for regent in Southeast Aceh. But the Batak ethnic involvement in Southeast Aceh Regency elections that the majority of the community Alas and Gayo has not been able to bring the ethnic Batak to reach the top leadership in Southeast Aceh. Batak ethnic involvement in Southeast Aceh Regency shows that the openness of democracy in Indonesia has come to the region of Southeast Aceh.
\end{abstract}

Keywords: Identity Politics, Ethnicity, Southeast Aceh, Election, Democracy

\section{INTRODUCTION}

The election is a process by which voters choose people to fill certain political positions. Political positions vary from the President, representatives at various levels of government to the village chief. The electoral system used in Indonesia are the principles of direct, public, free, confidential, as well as honest and fair. Various strategies for winning the election. Its objectives are to win public support for the proposed candidates of political parties in order to occupy political positions being contested through the electoral process.

Selection of the region is a long journey tinged politics of interests of the political elite and the public will, national and regional interests, or that between national and international interests ${ }^{1}$. In each of elections to the region, from the beginning to the end, starting from the moment the pair candidate registration, medical examination and determination of candidate, the announcement of the assets, taking the serial number, campaign exposure of the vision and mission, the debates, quiet week until the day election there is always evolving dynamics, such as the issue of ethnicity, religion and the politicization of religion, negative campaigning and voter list problems remain.

Post-New Orde (ORBA), the study of identity politics in Indonesia received special attention. At this time, the nuances of political studies of identity in Indonesia, more related to ethnicity, religion, ideology, and local interests are generally represented by the elites with respective articulation. Movement regional division can even be viewed as a form of identity politics. Issues of justice and regional development is central in political discourse, but, in truth, everything is much influenced by the ambition of problems that are not easy to describe (Maarif, 2012)2.

The resurrection of identity politics in Indonesia certainly can not solely rely on the national political changes which at first is centralized with the control of the New Orde (ORBA) regime and to encourage the development of regional autonomy and identity politics in Indonesia. Sri Astuti Buchari describes, autonomy and democracy are central issues that color the world of Indonesian politics. Movement of change inherent in the

\footnotetext{
1 Joko, J.Prihatmoko, Pengantar Kacung Marijan : Mendemokrasikan Pemilu : dari sistem sampai elemen teknis (Yogyakarta: Lembaga Penelitian, Pengembangan, dan Pengabdian Masyarakat, Universitas Wahid Hasyim Semarang,2008, 157

${ }^{2}$ Maarif,Ahmad,2012. Politik Identitas dan Masa Depan Pluralisme Kita. Jakarta: Yayasan Abad Demokrasi
} 
politics of regional autonomy spread to various parts of the country (Buchari, 2014) ${ }^{3}$.

The society itself can not relinquish the ethnicity factor in determining the choice of candidate Regent who competes in the direct elections. Thus, political behavior has to do with ethnicity.

Therefore, it is interesting to be politically emergence of ethnic issues occurs in massive rhythm in various shades of political celebration. The process of ethnic identity politics in the elections in Southeast Aceh become a concrete reality on the political dynamics of ethnicity continues to be constructed to achieve the desired political power by political actors in any political chance in Southeast Aceh.

Ethnicity is an important factor in the conduct of elections in Indonesia. Ethnic groups have a major role in shaping attitudes, perceptions, and the orientation of a person. Their sense of tribalism or regionalism affects one's support to political parties. Ethnicity may affect a person's loyalty to a particular party.

According to Castells (Munandar, 2013) ${ }^{4}$ in a world with a swirl of wealth, power and imagination of global scale, the search for identity, both collective and individual into the most basic source of the meaning of the fundamental source of meaning. The search for identity and meaning is not something completely new because the particular identity based on religion and ethnicity has been the root meaning of human life since the present civilization on earth. However, today, in a historical period marked by destructuring delegitimation organizations and institutions, has eliminated the social movements that have a major impact and cultural expressions are temporary.

In other words, although not the only, but the identity of a source of major significance. People increasingly organize, organize them the meaning of life is not about what they are doing, however, is based on what they believe.

\footnotetext{
${ }^{3}$ Buchari, Sri Astuti,2014. Kebangkitan Etnis Menuju Politik Identitas. Jakarta: Yayasan Obor Indonesia

4 Munandar, Aris.2013. Nasionalisme dan Identitas Komunitas Perbatasan Studi kasus pada Kabupaten Sambas Kalimantan Barat. Depok: Fisip Sociology of the University of Indonesia.
}

Meanwhile, the global net of exchange instrumental (global networks of instrumental exchanges) selectively turning off and on individuals, groups, regions and even countries, according to their relevance in fulfilling the goals processed in the network logic

\section{METHODOLOGY}

This research method using the descriptive qualitative method. The methods of data collection include observation, interviews and documentation study. The qualitative method is a process of research and understanding is based on a methodology that investigates a phenomenon of social and human problems. In this approach, the researchers created a complex picture, examine the words, a detailed report of the views of respondents, and conducted a study on the situation experienced (John W. Creswell, 1998: 15) 5

Miles and Huberman (1994) in Basrowi and Sukidin (2002: 2) ${ }^{6}$ states that qualitative methods trying to uncover the uniqueness contained in individual, group, community, and/or organization in the daily life of a thorough, detailed, deep, and can accountable scientifically.

Data analysis technique is qualitative by observing, understanding and give the interpretation of each data or facts and tends to the meaning and descriptions described in narrative form and words into a sentence ${ }^{7}$.

\section{RESULTS AND DISCUSSION}

\section{A.Batak Ethnic Migration Into Southeast Aceh}

Is known by the Dutch colonial government de vide et impera politics in mastering the archipelago. Then the opening of access to transport for mobility crops and their natural resources exploration highly preferred. Transportation access shall include construction of a new road from East Sumatra to Southeast Aceh (1909-1914). Making it easier for the next interethnic migration, among others Melayu Deli of East Sumatra, Batak Toba Samosir and surrounding areas. Including from Angkola, Sipirok, Batak

\footnotetext{
Creswell, John W. 1998 Qualitative Inquiry and Research Design, Choosing Among Five Traditions. California: Sage Publications. It 65.

6 Basrowi and Sukidin.2002. Metode Penelitian Kualitatif Persfektif Mikro. Surabaya. Insan Cendikia.

${ }^{7}$ Gorda, I Gusti Ngurah, 1997. Metode Penelitia Ilmu Sosial. Denpasar: PT. Widya Aksara National
} 
Timur Raya, Simalungun, Karo, Pakpak, Mandailings, Singkil, and others (Gayo, 1983). Besides, as a soldier Nica Netherlands, many workers and pave the way brought from Java, Manado, Batak Toba, etc., until today has been bred in Southeast Aceh. They are suspected to be the source of information for the Batak Toba and other tribes to come in later to Southeast Aceh Regency $^{8}$.

The opening of the road from Sidikalang to Southeast Aceh (1909-1914) became a source of information for Batak Toba people who came in later. That information comes from workers who were taken by the Dutch Colonial on Samosir.

Frederich Sibarani of Laguboti and his colleagues working in the field of construction of bridges in the territory Keujeuruen / Bambel kingdom. 1918 F. Sibarani and his family eventually settled in Titi Panjang, Village Prapat Hilir, Keujeuruen Batumbulan, where he opened a business. Later, the family has become a temporary shelter for the new arrivals of Tapanuli.

The arrival of the first Batak Toba lives in Keujeuruen Batumbulan. King Batumbulan then, Teuku Sidun, was pleased to new comers Batak Toba for successfully opening the rice fields. News about the Alas Land (Southeast Aceh) is increasingly spreading among farmers Batak Toba and they want to enter Alas Land. 1919 David Sitohang pleading letter from Brinkschmidt, a German pastor in Sidikalang, for Civil Gezaghhebber in Southeast Aceh so that they can open a settlement there.

The first years of the 1920s farmers increasingly crowded Batak Toba arrive. To get the land they first pay customs and obtain a permit from Keujeuruen. 1922 estimated there are 150 families who settled in the Alas Land. They opened the forest to shelter and agricultural land. Dutch Colonial parties feel happy and provide support and services for them to open the township. the first village of Batak Toba in Alas Land include Bunge Melur, Mbacang Racun, and Lawe Kulok.

In 1926 there were 8 (eight) Batak Toba village and six of them have already had their own

\footnotetext{
${ }^{8}$ Akbar, Talib 2004, Sanksi dan Denda Adat Alas, Kutacane
}

village chief of the tribe. When it is estimated there are 200 house holds in the country Batak Toba in Alas Land. According to the 1930 census, there are 1,789 Batak Toba people in Alas Land.

\section{a. Batak Ethnic identity politics}

Identity politics is an ideology that is present in every ethnic, latent and potential existence and at times can come to the surface as a dominant political force 9 . Empirically, the politics of identity is constructed actualization of political participation of the cultural roots of the local community, and undergo a process of internalization continuously in culture fabric of society in a social interaction. Political identity is an individual's participation in social life is determined by one's cultural and psychological. Identity is the foundation of the construction process and psychocultural culture of an individual who gives meaning and purpose of that individual, because, identity formation is the process of internal dialogue and social interaction.

In the context of the emergence of in Southeast Aceh district Batak ethnic identity politics that takes place beginning with the election of Regent in the Southeast Aceh in 2017. Internally, it happened because of the autonomy and democracy. The presence of identity politics that, externally conditioned by changes in the constellation of social and political at the national level are more open and democratic, which includes among others interpreted in the form of regional autonomy with broad authority and real which regulates elections and local elections that the process is done directly.

The election of Regent 2017 in Southeast Aceh, is true, it is a political contest that at least one ethnic bracing for decades yet to appear as the main fighter in the election of the Regent. Ethnic newly featured competing candidates with ethnic has long been a Regent Selection subscription, Alas tribe represented by Raidin - Bukhari. While for the Selection of Regents for the first time in February 2017 led to the ethnic Batak as a candidate for regent.

Ethnic identity development interests will arise by itself when the community is able to unite the ethnic Batak strengthen relationships with them

${ }^{9}$ Salim, Kamaruddin.2015. Politik Identitas Maluku Utara: Jurnal Kajian Politik dan Masalah Pembangunan. Vol.11. No.02: 1667-1678. 
through the Batak ethnic interests existence to show them in the midst of the majority society. Tarin Pdt. Fajar S.Th, in a media saying that: Batak people should use their right to vote in the upcoming ballot, do not vote, and would elect leaders who can help the community, he said. People (tribe) Batak must remember that he was the salt and light of the world (agent of change), and pray for the welfare of the city where he lives ${ }^{10}$.

With the interests of the struggle of ethnic Batak they are able to build the strength to support candidates for regional heads who have the same ethnic backgrounds although different religions, since the majority of Batak ethnic in Southeast Aceh district is Christian, but religious differences are not making them choose the option to keep their ethnic backgrounds the same as them.

The bond of ethnic primordialism became one of the important reasons of society in making choices. If a candidate has a background of primordial bonds similar to that of the primordialism of society, then that becomes an alternative choice of society. This emotional bond becomes an important consideration for the community to make its choice. It is seen on the basis of community communities in electoral districts, regions or areas of mass base characterized by the presence of party symbols that provide an overview and at the same time a sign that in the region is a bag of mass base of a particular party.

It is, as was done by the DPC Golkar Southeast Aceh Election in February 2017, where for the area and the location of that fact is the ethnic Batak, banners and large billboard that essentially invites the public to support the candidate pair number 2 (two), Ali Basrah and Deni F Roza so striking and dominant once. Things like this can easily be found in the subdistrict of Semadam, Deleng Pokhkison, Babul Makmur and surrounding areas. Moreover, the majority of people in the area are ethnic Batak so prone to be influenced by ethnic issues as well as

10 Lubis, fence. 2017. Mencermati Keberadaan orang batak dan pengaruhnya di Aceh Tenggara. Baranewsaceh, (online) ,(http://baranewsaceh. co/category/pilkada-aceh-tenggara/), diakses, 20 September 2017) the vision and mission programs can easily be accepted by the people around the area.

Theoretically, ethnicity can be a serious issue in the election, but in the 2017 General Election in Southeast Aceh ago, the issue of ethnicity had no negative impact or even conflict, so until after counting can take place smoothly and without significant interference. Politicization of ethnicity in Southeast Aceh Election can be addressed clearly by the public.

As one of the multi-ethnic region, the people of Southeast Aceh considered quite open and very respectful of the values of togetherness. Southeast Aceh community consists of a plurality of side by side and works together, both in terms of the social, political, economic, legal and cultural, so that the Southeast Aceh developed into an area of the region is the very fast-growing economy.

\section{b. Language As a form of Identity in Elections}

Ethnic Identity marked by symbols of culture, language, organization and their ideology. Each ethnic identities should be respected by the community to interact with each other (Eriksen:1993) ${ }^{11}$. Culturally ethnic distinctiveness makes humans unique in the communication as well as a separate study of anthropologists and communication experts. One thing that stands out in a person's social interaction, especially in the context of communication that involves people of different ethnicity is language. Language exchange in addition to its function as a transformer meaning of the message, the function of inheritance of social values so prominent.

Harris and Reilly (2000) ${ }^{12}$ say that language is a central issue in ethnic politics. Fortunately, it is easy to deal with the issues compared with another ethnic issue because the language allows multiidentity. Knowledge of language is not an exclusively ethnic granting or remained almost similar to religion or race. Humans can speak several languages and a couple of these languages coexist.

11 Eriksen, Thomas Hilland, 1993, Ethnicity and Nationalism (Anthropological perspective) Pluto Press, London.

12 Peter Harris and BenReilly (ed) Democracy and Rooted Conflict: Options for Negotiators number, (translated by LP4M), First edition, 2000, Ami Rependi, Ameepro 
The use of language in communication has received the attention of every prospective head region both in the region and in the region where he lives which became the target of the regional head candidates to campaign and socializing. And also carried out by the prospective head region. Using everyday language to communicate becomes a positive value because it will get the sympathy of the community as well as in communication at the time of the formal events, such as giving a speech with the usual local language and also continued with socialization convey intent and purpose of their arrival.

Using non-formal language in interpersonal communication is considered more touching to the feelings of local people compared to formal or Indonesia language communication. The use of the local language will feel the closeness personally when invited to speak by using everyday language or languages commonly used by the group. In contrast, if using a formal language, usually people are also reluctant or unwilling to engage deeply in discussions.

\section{CONCLUSIONS}

The results of research conducted in Southeast Aceh Regency found that ethnicity relationships against the political choices of people in Southeast Aceh in February 2017 that just done tends to be significant. This is because the contest in the general election contest is only followed by two pairs of candidates with different ethnic backgrounds, namely Alas and Batak, so the choice of candidate regent/deputy regent tends to fellow ethnic.

The association of ethnic primordialism became an important reason for the society in addressing the selectivity of candidates, the bond became an important consideration for the community in determining its political choice in the Southeast Aceh elections. This can be seen in the sub-districts of which Batak ethnic majority, Ali Basrah-Deni F Roza pair can surpass their opponents with the number of differences in votes far enough.

\section{ACKNOWLEDGMENT}

The author would like to thank the graduate program of Medan State University, especially the lecturers of Social Anthropology Postgraduate, who gave me the opportunity to gain knowledge and guide me in making this paper.

\section{REFERENCES}

Akbar, Thalib, 2004, Sanksi dan Denda Tindak Pidana Adat

Alas, Kutacane

Buchari, Sri Astuti. 2014. Kebangkitan Etnis Menuju Politik

Identitas. Jakarta: Yayasan Obor Indonesia.

Basrowi dan Sukidin.2002. Metode penelitian kualitatif

perspektif mikro. Surabaya. Insan Cendikia.

Creswell, John W. 1998, Qualitative Inquiry and Research California:

Design, Choosing Among Five Traditions.

Sage Publication. Hal 65.

Gorda, I Gusti Ngurah, 1997. Metode Penelitian Ilmu Sosial.

Denpasar: PT. Widya Aksara Nasional

Eriksen, Thomas Hilland, 1993, Ethnicity, and Nationalism

London.

(anthropological perspective) Pluto Press,

Joko J. Prihatmoko, pengantar Kacung Marijan :

Mendemokrasikan Pemilu : dari sistem sampai

elemen teknis (Yogyakarta: Lembaga

Penelitian,

Pengembangan, dan Pengabdian Masyarakat,

Universitas Wahid Hasyim Semarang, 2008), 157.

Lubis, pagar. 2017. Mencermati keberadaan orang batak dan

pengaruhnya di Aceh Tenggara.

Baranewsaceh, 
(online),

(http://baranewsaceh.co/category/pilka da-

aceh-tenggara/), diakses 20 September 2017)

Maafif, Ahmad Syafii. 2012. Politik Identitas dan Masa

Abad

Depan Pluralisme Kita. Jakarta: Yayasan

$$
\text { Demokrasi }
$$

Munandar, Aris.2013. Nasionalisme dan Identitas Komunitas

Sambas

$$
\text { Perbatasan Studi Kasus Pada Kabupaten }
$$

Kalimantan Barat. Depok: Fisip Sosiologi

Universitas Indonesia.

Peter Harris dan Ben Reilly (ed) Demokrasi dan Konflik yang

Mengakar: Sejumlah Pilihan untuk Negosiator,

(diterjemahkan oleh LP4M), Cetakan pertama, 2000,

\section{AMEEPRO}

Salim, Kamaruddin.2015. Politik Identitas di Maluku Utara:

Jurnal Kajian Politik dan Masalah Pembangunan.

Vol.11. No.02:1667-1678. 